\title{
Article \\ Chromosomal Polymorphism and Speciation: The Case of the Genus Mazama (Cetartiodactyla; Cervidae)
}

\author{
David Javier Galindo ${ }^{1}\left(\right.$, Gabriela Siqueira Martins ${ }^{2}{ }^{\oplus}$, Miluse Vozdova ${ }^{3}{ }^{\oplus}$, Halina Cernohorska ${ }^{3}$, \\ Svatava Kubickova ${ }^{3}$, Agda Maria Bernegossi ${ }^{1}{ }^{1}$, Dita Kadlcikova $\left.{ }^{3}{ }^{(}\right)$, Jiri Rubes ${ }^{3}$ and \\ José Maurício Barbanti Duarte ${ }^{1, *} \mathbb{B}$ \\ 1 Núcleo de Pesquisa e Conservação de Cervídeos, Faculdade de Ciências Agrárias e Veterinárias, \\ Universidade Estadual Paulista—NUPECCE/FCAV/UNESP, 14884-900 Jaboticabal, Brazil; \\ dgalindoh89@gmail.com (D.J.G.); agm.bernegossi@gmail.com (A.M.B.) \\ 2 Laboratório de Dosagens Hormonais, Faculdade de Medicina Veterinária e Zootecnia, \\ Universidade de São Paulo-FMVZ/USP, 05508-270 São Paulo, Brazil; gabriela.smartins88@gmail.com \\ 3 Department of Genetics and Reproductive Biotechnologies, Central European Institute of \\ Technology—Veterinary Research Institute, 621-00 Brno, Czech Republic; vozdova@vri.cz (M.V.); \\ cernohorska@vri.cz (H.C.); kubickova@vri.cz (S.K.); kadlcikova@vri.cz (D.K.); rubes@vri.cz (J.R.) \\ * Correspondence: mauricio.barbanti@unesp.br
}

check for updates

Citation: Galindo, D.J.; Martins, G.S.; Vozdova, M.; Cernohorska, H.; Kubickova, S.; Bernegossi, A.M.; Kadlcikova, D.; Rubes, J.; Duarte, J.M.B. Chromosomal Polymorphism and Speciation: The Case of the Genus Mazama (Cetartiodactyla; Cervidae). Genes 2021, 12, 165. https://doi.org/10.3390/ genes12020165

Academic Editor: Taras K. Oleksyk Received: 31 December 2020

Accepted: 23 January 2021

Published: 26 January 2021

Publisher's Note: MDPI stays neutral with regard to jurisdictional claims in published maps and institutional affiliations.

Copyright: (c) 2021 by the authors. Licensee MDPI, Basel, Switzerland. This article is an open access article distributed under the terms and conditions of the Creative Commons Attribution (CC BY) license (https:/ / creativecommons.org/licenses/by/ $4.0 /)$.

\begin{abstract}
Chromosomal polymorphism plays a major role in speciation processes in mammals with high rates of karyotypic evolution, as observed in the family Cervidae. One remarkable example is the genus Mazama that comprises wide inter- and intra-specific chromosomal variability. To evaluate the impact of chromosomal polymorphisms as reproductive barriers within the genus Mazama, inter-specific hybrids between Mazama gouazoubira and Mazama nemorivaga (MGO $\times$ MNE) and intra-specific hybrids between cytotypes of Mazama americana (MAM) differing by a tandem $(\mathrm{TF})$ or centric fusion (Robertsonian translocations-RT) were evaluated. MGO $\times$ MNE hybrid fertility was evaluated by the seminal quality and testicular histology. MAM hybrids estimation of the meiotic segregation products was performed by sperm-FISH analysis. MGO $\times$ MNE hybrids analyses showed different degrees of fertility reduction, from severe subfertility to complete sterility. Regarding MAM, RT, and TF carriers showed a mean value for alternate segregation rate of $97.74 \%$, and $67.23 \%$, and adjacent segregation rate of $1.80 \%$, and $29.07 \%$, respectively. Our results suggested an efficient post-zygotic barrier represented by severe fertility reduction for MGO $\times$ MNE and MAM with heterozygous TF. Nevertheless, RT did not show a severe effect on the reproductive fitness in MAM. Our data support the validity of MGO and MNE as different species and reveals cryptic species within MAM.
\end{abstract}

Keywords: cytogenetics; hybrids; post-zygotic barrier; sperm-FISH; Neotropical deer

\section{Introduction}

Chromosomal polymorphisms have played a meaningful role in speciation [1], by leading to the formation of efficient barriers to gene flow and subsequent differentiation process [2,3]. Among mammals, the family Cervidae stands out as one of the families with the highest presence of chromosomal polymorphisms, which is demonstrated in genera such as Muntiacus, whose diploid number ranges from $2 n=6 / 7$ (Muntiacus muntjak) to $2 n=46$ (Muntiacus reevesi) [4,5], and Mazama, whose diploid number ranges from $2 \mathrm{n}=32$ $34+\mathrm{Bs}$ (Mazama bororo-MBO) to $2 \mathrm{n}=70+\mathrm{Bs}$ (MGO) [6-8]. Intra-specific polymorphism is also present in several Mazama species (Mazama nana-MNA, 2n = 36-39 + Bs; MAM, $2 n=42-53+$ Bs; MNE, $2 n=67-69+$ Bs) [9-11] which, in part, justifies the great complexity in the species taxonomic definition and classification.

Regarding the genus Mazama, the occurrence of chromosomal rearrangements, mainly heterozygous RT, has been observed in MGO, the only holder of the ancestral karyotype 
within the genus $[7,12,13]$. Presence of these RTs denotes a high index of chromosomal fragility in this species, which has been previously tested and corroborated by doxorubicininduced chromosomal aberrations $[14,15]$. Thus, we can hypothesize an ongoing speciation process in MGO [12]. Studies on deer mitochondrial DNA have suggest that MNE and MGO would not belong to the genus Mazama. Both of them standing in independent clades and distant from other Mazama, sharing the gray clade with other genera such as Blastocerus, Ozotoceros, and Hippocamelus [16,17]. In the meantime, this group is characterized by low levels of inter-specific chromosome difference and karyotypes with a high diploid number [11,16,17]. Due to their parapatric distribution [18] and morphological similarity, the differentiation between these two species has been the subject of extensive debate over the years, being demonstrated only recently through morphological $[19,20]$, cytogenetic $[11,20,21]$, and phylogenetic $[20,22]$ analyzes.

Indeed, the comparison between MGO and MNE karyotypes have demonstrated that despite notable cytogenetic similarities, two chromosomal differences separate these species: (a) The presence of a MNE population with a $\operatorname{rob}(4 ; 32)$, regarding to the base karyotype for the species, with a sex chromosome system $X X / X Y$ and a submetacentric $X$, different from the acrocentric $X$ of MGO, and (b) The presence of an $X$-autosome TF in other MNE population, which resulted in a multiple sex chromosome system XX/XY1Y2 $[7,8,11,20]$. The occurrence of these rearrangements, by themselves, is already a strong indication of their possible role in the separation of these two species, although more evidence is needed to corroborate this statement $[11,23]$.

Chromosomal polymorphisms are potent promoters of reproductive isolation since they can trigger a series of errors during meiosis in hybrids of different species or lineages, such as incorrect pairing of parental chromosomes, errors in chromosome segregation, and during crossing-over. These so-called meiosis defects have a deleterious effect on the individual's reproductive fitness, leading to subfertility or sterility [1,24]. Although a description of morphophysiological evidence for reproductive isolation needs further investigation within the gray clade, this does not seem to be the case of the second clade of the genus Mazama, the red clade.

Regarding the red clade, what was traditionally reported as MAM today is considered a complex of cryptic species with two chromosomal lineages, one with high diploid number (Cytotypes Paraná-PR, 2n = 52/53, FN = 56; Santarém-SA, 2n = 50/51, FN = 56; Jarí-JA, $2 \mathrm{n}=48 / 49, \mathrm{FN}=56$; and Carajás-CA, $2 \mathrm{n}=50 / 51, \mathrm{FN}=54)$ and one with a low diploid number (Cytotypes Juína-JU, 2n $=44 / 45, \mathrm{FN}=48$; and Rondônia-RO, $2 \mathrm{n}=42 / 43$, $\mathrm{FN}=46)$, all of them with wide geographical coherence [10]. Comparisons between cytotypes of the same lineage by G-banding showed minimal differences, such as TF or RT, from one cytotype to another [10].

A reproductive study on MAM showed that hybrids produced by crossbreeding of the two different chromosomal linages are sterile [25]. This indicated the occurrence of post-zygotic reproductive isolation between the MAM linages, which was associated with errors in meiotic recombination and gametic segregation due to several chromosomal differences, such as TF, RT, and inversions [25,26]. Hybrids between cytotypes of the same chromosomal lineage, with a chromosome number difference being equal to or less than 3 between the parents, were considered subfertile. Nonetheless, spermatogenesis was only evaluated in morphological and histological terms, without assessing the presence of chromosomally balanced or unbalanced gametes [25]. On the other hand, the presence of heterozygous RT in MAM probably only has a low effect on the reproductive fitness of the carrier [27].

This study aimed to assess the role of chromosomal polymorphism as a reproductive barrier and speciation mechanism within the genus Mazama. Thus, inter-specific hybrids between $M$. gouazoubira and M. nemorivaga $(\mathrm{MGO} \times \mathrm{MNE})$ and intra-specific hybrids between M. americana (MAM) cytotypes differing by TF or RT were evaluated. 


\section{Materials and Methods}

\subsection{Species and Samples}

Fibroblast tissue cultures prepared from skin biopsies according to standard protocols, testicular tissue, and sperm of M. gouazoubira (MGO), M nemorivaga (MNE), M. americana (MAM) cytotypes and hybrids, available at NUPECCE (Jaboticabal, São Paulo, Brazil), were used in the present study. For the inter-specific hybridization experiment, two hybrids between M. gouazoubira and M. nemorivaga and five pure bucks $(n=3, M$. gouazoubira and $n=2$, M. nemorivaga) were used and are described in Table 1.

Table 1. Summary of chromosomal data from M. gouazoubira, M. nemorivaga, and inter-specific hybrids.

\begin{tabular}{|c|c|c|c|c|c|c|}
\hline \multirow{2}{*}{ Animal } & \multirow{2}{*}{ Species } & \multirow{2}{*}{$2 n$} & \multirow{2}{*}{ FN } & \multicolumn{2}{|c|}{ Translocations } & \multirow{2}{*}{ B } \\
\hline & & & & RT & Multiple Sexual System & \\
\hline PG1 & M. gouazoubira & 70 & 70 & - & No & $0-2$ \\
\hline PG2 & M. gouazoubira & 70 & 70 & - & No & $0-2$ \\
\hline PG3 & M. gouazoubira & 70 & 70 & - & No & $0-2$ \\
\hline PN1 & M. nemorivaga & 68 & 72 & $\operatorname{rob}(4 ; 32)(4 ; 32)^{\mathrm{a}}$ & No & $1-9$ \\
\hline PN2 & M. nemorivaga & 67 & 70 & $\operatorname{rob}(4 ; 32)(4 ; 32)^{a}$ & Yes $^{\mathrm{a}}$ & $2-5$ \\
\hline $\mathrm{H} 1$ & MGOळా × MNEใ & 69 & 72 & $\operatorname{rob}(4 ; 32)^{a}$ & No & $0-3$ \\
\hline $\mathrm{H} 2$ & MNE $\mathscr{P} \times$ MGO & 70 & 70 & - & No & $0-2$ \\
\hline
\end{tabular}

$2 \mathrm{n}$ = chromosome number; FN = fundamental number; $\mathrm{RT}=$ Robertsonian translocation; $\mathrm{TF}=$ tandem fusion; $\mathrm{B}=$ supernumerary chromosomes. ${ }^{a}$ Chromosome classification according to standard karyotype for M. nemorivaga [11].

For the intra-specific hybridization experiment, two heterozygous Robertsonian translocation hybrids, three heterozygous TF hybrids, and two Carajás cytotype bucks from M. americana (MAM) were used. A detailed data of the animals is described in Table 2.

Table 2. Summary of chromosomal data from M. americana carriers of chromosomal translocations, hybrids of different MAM cytotypes, and non-translocated animals.

\begin{tabular}{|c|c|c|c|c|c|c|}
\hline \multirow{2}{*}{ Animal } & \multirow{2}{*}{ Cytotypes } & \multirow{2}{*}{$2 n$} & \multirow{2}{*}{ FN } & \multicolumn{2}{|c|}{ Translocations } & \multirow{2}{*}{ B } \\
\hline & & & & RT & TF & \\
\hline $\mathrm{T} 297^{\mathrm{a}}$ & Carajás & 51 & 54 & - & - & $2-3$ \\
\hline T274 & Carajás & 50 & 54 & $\operatorname{rob}(5 ; 11)^{\mathrm{b}}$ & - & 3 \\
\hline T326 & Carajás & 49 & 54 & $\operatorname{rob}(5 ; 11)(5 ; 11)^{b}$ & - & $3-4$ \\
\hline T269 & Rondônia & 42 & 46 & $\operatorname{rob}(7 ; 20)^{c}$ & - & $3-5$ \\
\hline T343 & Juína $\underset{F}{ } \times$ Rondônia & 43 & 47 & $\operatorname{rob}(7 ; 20)^{c}$ & $\operatorname{der}(7 ; 10)^{d}$ & $2-3$ \\
\hline T347 & 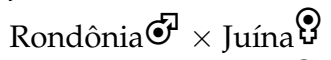 & 44 & 47 & - & $\operatorname{der}(7 ; 10)^{d}$ & $2-4$ \\
\hline $\mathrm{T} 421$ & Paraná $\underset{0}{ } \times$ Carajás $\$$ & 52 & 55 & - & $\operatorname{der}(5 ; 10)^{e}$ & - \\
\hline
\end{tabular}

2n = chromosome number; FN = fundamental number; $\mathrm{RT}=$ Robertsonian translocation; $\mathrm{TF}=$ tandem fusion; $\mathrm{B}=$ supernumerary chromosomes. ${ }^{a}$ Control bucks, normal karyotype. ${ }^{b}$ Chromosome classification according to Carajás cytotype [10]. ${ }^{\mathrm{c}}$ Chromosome classification according to Rondônia cytotype $[10,27]{ }^{\mathrm{d}}$ Chromosome classification according to Juína cytotype [28]. Rondônia chromosome $4=$ tandem fusion of Juína chromosomes $7+10 .{ }^{\text {e }}$ Chromosome classification according to Paraná cytotype [28]. Carajás chromosome $3=$ tandem fusion of Paraná chromosomes $5+10$.

\subsection{Whole-Chromosome Painting and Bacterial Artificial Chromosomes (BAC) Probes}

Bovine whole-chromosome painting (WCP) probes were used for identification of chromosomes involved in the Robertsonian and Tandem fusions in animals analyzed in this study. Bovine whole chromosomes were isolated by flow sorting using MoFlo XDP Cell Sorter (Beckman Coulter, Brea, CA, USA) [29] or microdissected by PALM Microlaser system (Carl Zeiss MicroImaging GmbH, Munich, Germany) [30]. Once isolated, bovine chromosomes were used to produce WCP probes by DOP-PCR [31]. Probe labeling was performed during the secondary PCR with Green-dUTP or Orange-dUTP (Abbott Park, Chicago, IL, USA) [30]. 
For sperm-FISH, bovine BAC clones localized to the chromosomes involved in translocations were selected from the CHORI-240 cattle library (BACPAC Genomics, Emeryville, CA, USA). BAC DNA labeling was with digoxigenin-11-dUTP or biotin16-dUTP (Roche, Mannheim, Germany) was performed using BioPrime Array CGH Genomic Labeling Module (Invitrogen, Carlsbad, CA, USA). Detailed list of BACs used in the present study appears in Table S1.

\subsection{FISH}

FISH and sperm-FISH procedures were carried out as described in Vozdova et al. 2019 [32]. BAC probes labeled with digoxigenin-11-dUTP were detected with antidigoxigenin rhodamine (Roche Diagnostics, Indianapolis, IN, USA). BAC probes labeled with biotin-16-dUTP were detected with Avidin-FITC (Vector Laboratories, Inc., Burlingame, CA, USA). Hybridization signals were examined using Zeiss Axio Imager.Z2 fluorescence microscope (Carl Zeiss Microimaging $\mathrm{GmbH}$, Jena Germany) equipped with appropriate fluorescent filters and the Metafer Slide Scanning System (MetaSystems, Altlussheim, Germany). Images of well-spread metaphase cells were captured and analyzed using ISIS3 software (MetaSystems, Altlussheim, Germany).

\subsection{Inter-Specific Hybrids (MGO $\times$ MNE) Reproductive Assessment}

\subsubsection{Spermiogram}

All animals went through at least one semen collection procedure once they achieved adulthood ( $<12$ months of age). Electroejaculation procedure followed Favoretto et al. (2012) [33]. In short, all animals were anaesthetized intramuscularly with a combination of xylazine $(1 \mathrm{mg} / \mathrm{kg})$ and ketamine hydrochloride $(7 \mathrm{mg} / \mathrm{kg})$. Following sedation, a probe was inserted into the rectum and placed against the anterior wall close to the seminal vesicles. Each animal was submitted to sequential electroshocks increasing from $250 \mathrm{~mA}$ to $750 \mathrm{~mA}$, with a mean duration of $3 \mathrm{~s}$ (and $3 \mathrm{~s}$ of rest). Three stimulation sequences of 10 shocks each were performed at intervals of 1-2 min [34]. Collected samples were maintained in microtubes $(2 \mathrm{~mL})$ at $37^{\circ} \mathrm{C}$ in water bath until the beginning of analysis. Ejaculate color was determined by a single researcher to avoid any individual biases. Volume, total motility, sperm vigor, and sperm count were evaluated as described by Alvarez et al. (2020) [35]. Morphological analysis of the ejaculate was performed through the examination of wet preparations of fixed spermatozoa under phase contrast microscope. Morphological defects were classified according to their origin, to detect defects arising from an anomalous spermatogenesis (primary defects, resulting from testicular and secondary defects, resulting from inadequate maturation) [36].

\subsubsection{Testicular Histology}

PG1, PG2, PN1, and H1 underwent unilateral orchiectomy after electroejaculation procedure. PG3, PN2, and $\mathrm{H} 2$ had their testicles collected immediately post-mortem. Testicular tissue was grossed into $1 \mathrm{~cm}$ thick sections, fixed in Bouin's fixative for $24 \mathrm{~h}$, processed for paraffin embedding, microtome-sectioned at $5-\mu \mathrm{m}$ thickness, stained with hematoxylin and eosin, and imaged with a microscope. Then, 60 round or nearly round tubular profiles from each animal were randomly chosen and had diameter and epithelium height measured (Axio Vision v. 4.8.2, Carl Zeiss AG, Feldbach, Switzerland) size measurement tools were used). Ten sections of seminiferous tubules were analyzed to quantify the population of sperm cells. The results were presented with mean \pm SD.

\subsection{Intra-Specific Hybrids (MAM) Reproductive Assessment}

\subsubsection{Semen Samples and Sperm Nuclei Preparation}

Cryopreserved semen samples were obtained from NUPECCE's germplasm bank. Ejaculates were collected and cryopreserved with Tris-egg yolk-glycerol extender [33]. To perform decondensation of the sperm nuclei, the method described by Rubes et al. (1999) was used, with slight modifications [37]. Briefly, semen samples were thawed at 
$37^{\circ} \mathrm{C}$ for $20 \mathrm{~s}$. Samples were transferred to a $2 \mathrm{~mL}$ Eppendorf tube, then washed with $500 \mu \mathrm{L}$ of phosphate-buffered saline (PBS, pH 7.2), centrifuged at $380 \mathrm{~g} \mathrm{(5} \mathrm{min),} \mathrm{and} \mathrm{the}$ supernatant discarded (repeated $3 \times$ ). Pellet was resuspended in $500 \mu \mathrm{L}$ of PBS containing $5 \mathrm{mM}$ dithiothreitol (DTT), and incubated for 40-60 $\mathrm{min}$, with slight homogenization every $10 \mathrm{~min}$, then centrifuged. Pellet was washed in $300 \mu \mathrm{L}$ of PBS $(3 \times)$, and then fixed in Carnoy solution (3:1 methanol:acetic acid) $(3 \times)$. Finally, samples were stored at $-20{ }^{\circ} \mathrm{C}$ (30 $\mathrm{min}$ ) in Carnoy solution. For dropping onto clean microscope slides, samples were diluted to a desired concentration.

\subsubsection{Sperm-FISH}

The FISH protocol described in Section 2.3 was used with a slight modification for sperm denaturation. Briefly, spermatozoa were denatured in $1 \mathrm{M} \mathrm{NaOH}$ for $6-10 \mathrm{~min}$. BAC probes labeled with digoxigenin-11-dUTP and biotin-16-dUTP were detected with antidigoxigenin rhodamine and Avidin-FITC, respectively. Scoring of normal/balanced and unbalanced gametes was performed using Zeiss Axio Imager.Z2 fluorescence microscope. Only intact, non-overlapping gametes were scored using strict scoring criteria. The sperm was considered disomic if it showed two signals of the same color, size, and intensity, separated by a distance of at least one signal domain size. Diploid spermatozoa were differentiated from the double disomic ones by their larger size.

\subsection{Statistical Analysis}

Results for the histological measurements and the percentage of intratubular cells were presented by mean $\pm \mathrm{SD}$. All the results were submitted to Shapiro-Wilk normality test. Tubular diameter and germinal epithelium height did not present normal distribution therefore individual means were compared using non-parametric Kruskal-Wallis teste followed by pairwise Mann-Whitney U test with Bonferroni correction. Seminal parameters from hybrids between MGO and MNE and "pure" bucks were descriptively compared. Non-parametric Mann-Whitney exact test and Wilcoxon signed-rank test were used to compare frequencies of different segregation products between individuals and to compare FISH phenotypes per each chromosome, respectively. Meiotic segregation patterns were analyzed using the Kruskal-Wallis test and the difference between groups was obtained using the Dunn's multiple comparison test, adjusted by Bonferroni. All analyzes were performed using Software R (R Foundation, 2020) [38] and $p<0.05$ was considered significant.

\section{Results}

Using FISH with bovine WCP probes, we identified homologies between bovine chromosomes and the translocated chromosomes in the analyzed brocket deer hybrids. Chromosome differences between MGO and MNE identified by FISH with bovine WCP probes are shown in Figure 1. The FISH analysis of the hybrids showed that buck H1 obtained the $\operatorname{rob}(4 ; 32)$ (Figure 2A) and the submetacentric X of MNE. The buck H2 did not inherit the X-autosomal fusion of MNE, but the acrocentric $\mathrm{X}$ of MGO.

Regarding MAM, differences between a non-translocated, heterozygous, and homozygous rob $(5 ; 11)$ in the Carajás cytotype are shown in Figure 2B-D. Difference between Rondônia $(2 \mathrm{n}=42 / 43)$ and Juína $(2 \mathrm{n}=44 / 45)$ cytotypes, as well as Carajás $(2 \mathrm{n}=50 / 51)$ and Paraná $(2 \mathrm{n}=52 / 53)$ cytotypes, was confirmed by FISH with bovine WCP and BAC probes, revealing a TF (centromere-telomere) (Figure 2E,F). Heterozygous TF in the hybrids was classified according to Abril (2009) [28], where a der(7;10) in Juína and a der(5;10) in Paraná are equivalent to the acrocentric chromosomes 4 in Rondônia and 3 in Carajás, respectively. 


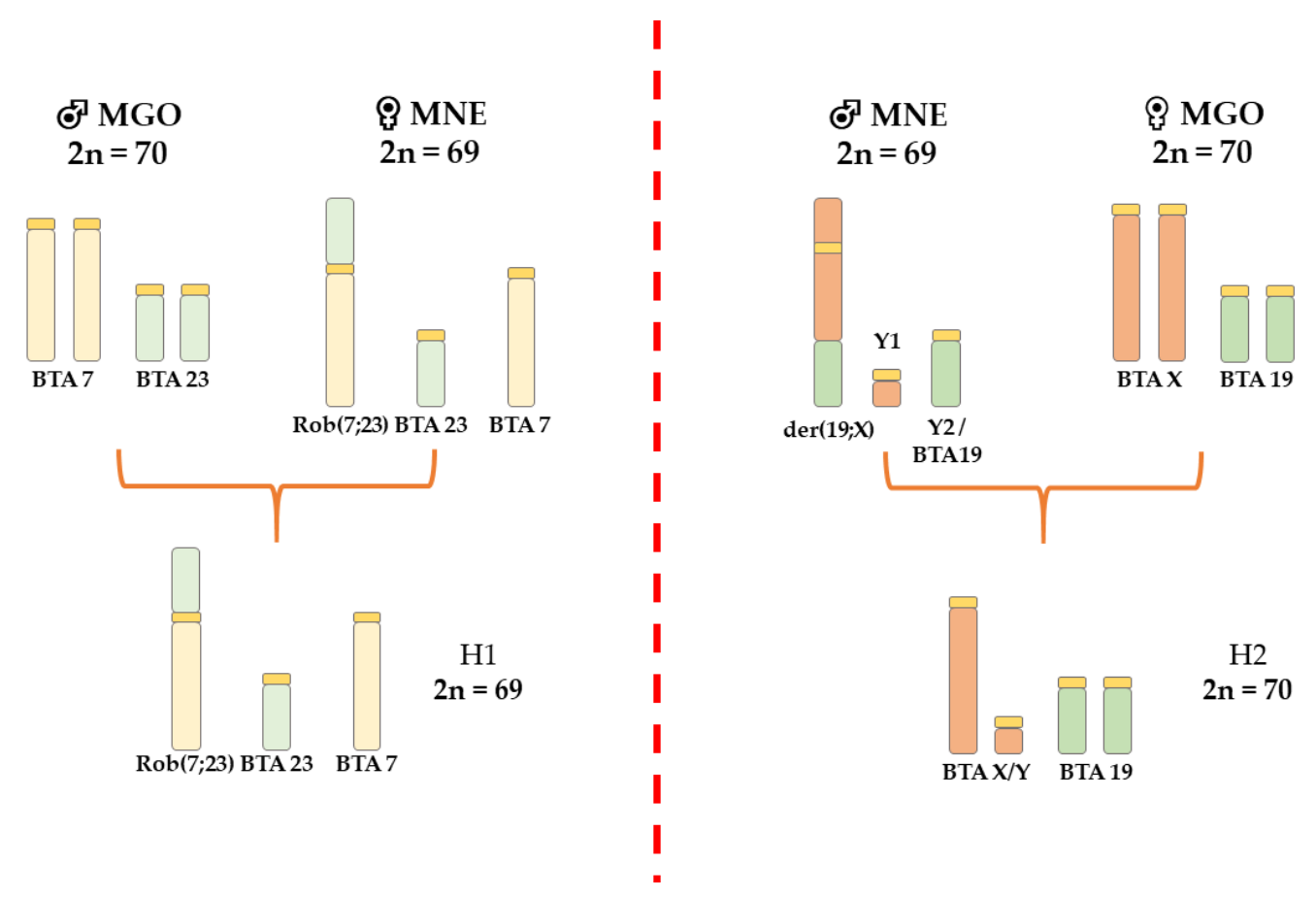

Figure 1. Schematic illustration showing the chromosomal polymorphism involved in the formation of MGO $\times$ MNE hybrids with orthologous bovine chromosomes.

\subsection{Inter-Specific Hybrids}

The fertility of pure and hybrids bucks $(\mathrm{MGO} \times \mathrm{MNE})$ was assessed by testicular and sperm analysis. Photomicrographs of the testicular tissue revealed three distinct testis histology phenotypes (exemplified in Figure 3A-D) among pure animals and both hybrids. MGO and MNE testis $(\mathrm{A}, \mathrm{B})$ were considered totally functional, with multiple round tubules containing a plush spermatogenic epithelium. Morphometric measurements (Figure 3E,F) revealed larger tubules and thicker seminiferous epithelium, with PG3 presenting the highest mean values for tubular diameter and epithelium height among all individuals. Spermatogenesis was active and uniform in all sections analyzed, which was later confirmed by the quantification of sperm cells (Table 3) and the higher spermatid-tospermatocyte ratio (SSR) values (1.50-4.19).

Regarding hybrids, histology phenotypes presented different levels of testicular hypoplasia as well as epithelial vacuolization suggestive of apoptosis. In H1, all the seminiferous tubules analyzed were hypoplastic (Figure 3C) with evidence of spermatogenesis interruption during the first meiosis (SSR = 0, Table 3). H1 showed significant lower mean diameter and epithelium height $(p<0.05)$ among all the animals analyzed. H2, in turn, seemed to be affected to a lesser extent, with the majority $(90 \%)$ of seminiferous tubules being considered active (Figure 3D), even though spermatogenesis was complete in only part of them (demonstrated by reduction in later cell types, SSR $=0.84$ ). Morphometric means for $\mathrm{H} 2$ did not significantly differ from most pure bucks (PG1, PG2, and PN2).

The seminal parameters are presented in Table 4. Overall, despite the species, pure individuals performed better than hybrids in most of the parameters evaluated. Seminal parameters of pure MGO and pure MNE remained rather consistent between both species and within the values of reference for them [39]. Regarding sperm morphology, in general, primary defects were more frequent in most animals. On the other hand, hybrid H1 was azoospermic, while the seminal analysis of hybrid H2 showed a remarkably low concentration, sparse motile sperm cells, and a high percentage of sperm defects (90\%). Most of the defects were in the sperm flagellum and head. 

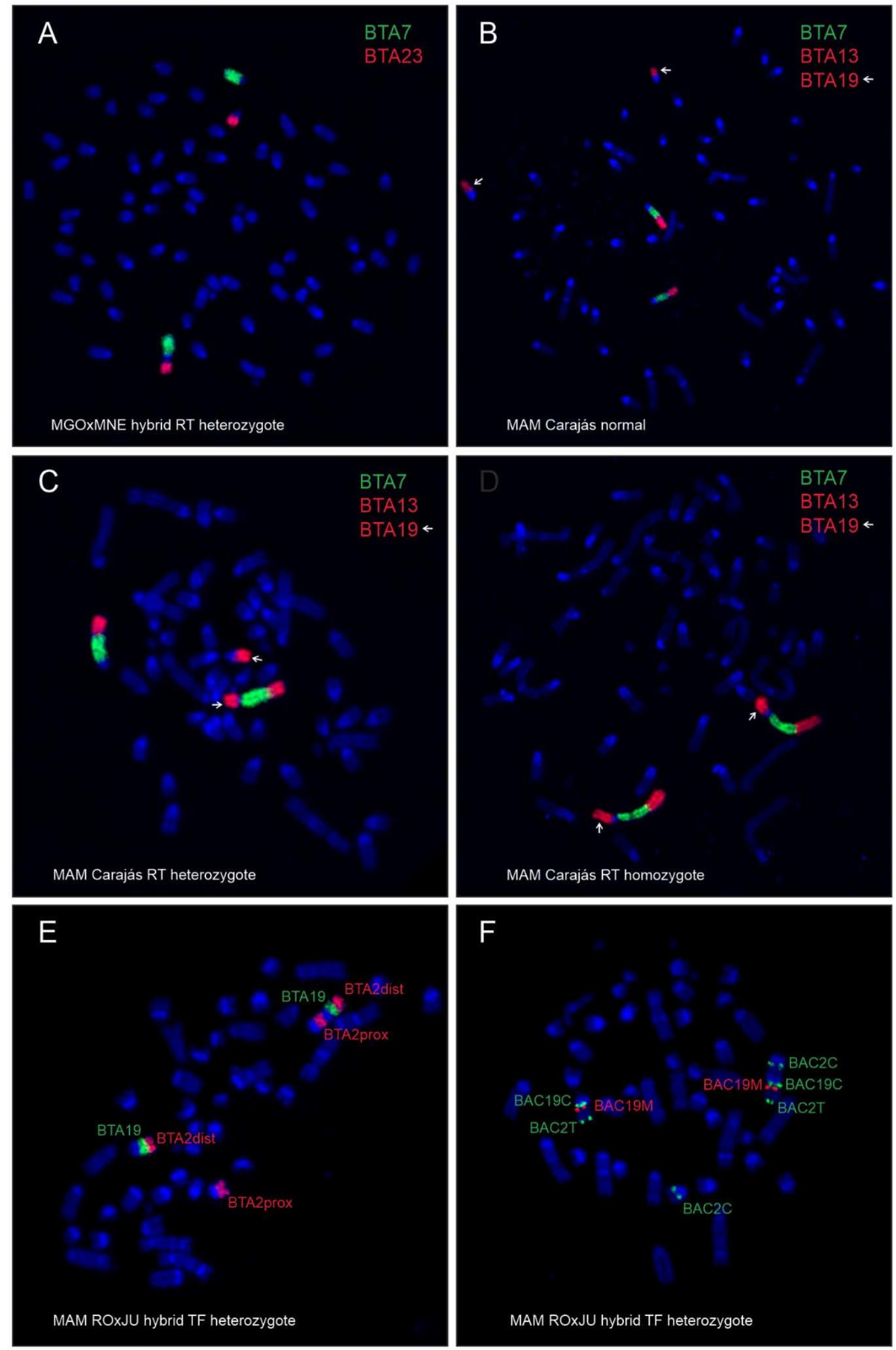

Figure 2. Metaphase chromosomes of the analyzed animals after FISH with bovine WCP (A-E) and BAC (F) probes. (A) Hybrid H1 (M. gouazoubira $\times$ M. nemorivaga) heterozygous for rob(4;32). (B) M. americana T297, Carajás cytotype, with normal karyotype. (C) M. americana T274, Carajás cytotype, heterozygous for rob(5;11). (D) M. americana T326, Carajás cytotype, homozygous for rob(5;11). (E) M. americana T343, Rondônia $\times$ Juína cytotype hybrid heterozygous for tandem fusion der(5;11) with WCP probes. (F) M. americana, Rondônia $\times$ Juína cytotype hybrid heterozygous for tandem fusion der( $5 ; 11)$ with BAC probes. 


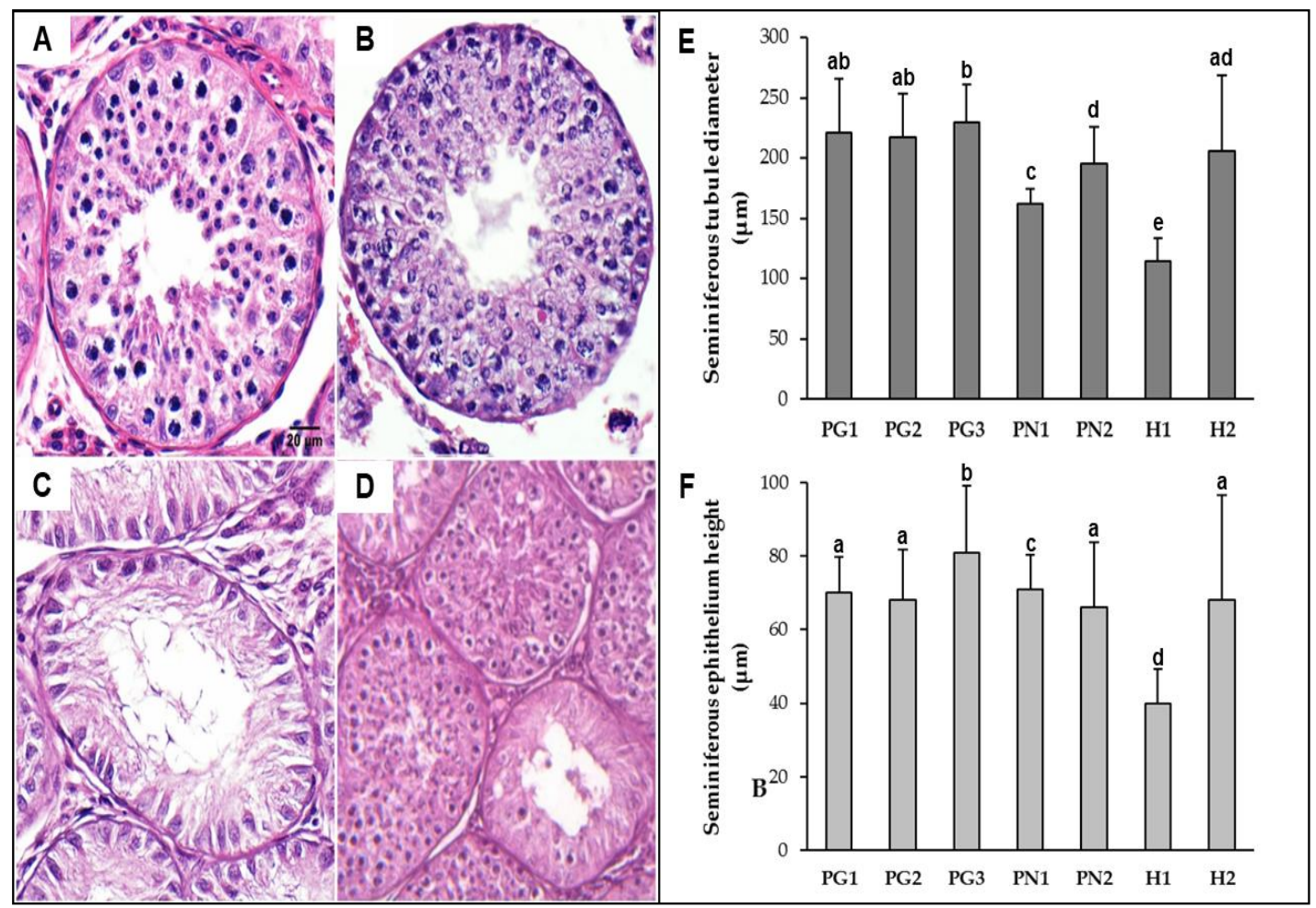

Figure 3. Morphometric differences between M. gouazoubira (PG), M. nemorivaga (PN) and inter-specific hybrids (H) testes (A-D); Histological sections of testes (scale bar = $20 \mathrm{~mm}$ ); (A) Fertile PG buck; (B) fertile PN buck; (C) sterile hybrid buck (H1), note hypoplastic aspect of tubules and absence of spermatozoa in tubule lumen; (D) subfertile hybrid buck (H2), note juxtaposition of defective and functional seminiferous tubule cross-sections; (E) mean diameters of seminiferous tubules; and (F) mean seminiferous epithelium height. Columns followed by the same letter do not differ according to the Mann-Whitney U test $(p<0.05)$.

Table 3. Mean \pm standard deviation of the percentages of cell types of the seminiferous epithelium of adult males $M$. gouazoubira (PG), M. nemorivaga (PN) and inter-specific hybrids (H).

\begin{tabular}{|c|c|c|c|c|c|c|c|}
\hline Animal & $\begin{array}{c}\text { Spermatogonia } A \\
(\%)\end{array}$ & $\begin{array}{c}\text { Spermatogonia B } \\
(\%)\end{array}$ & $\begin{array}{c}\text { Leptotenes/Zygotenes } \\
(\%)\end{array}$ & $\begin{array}{l}\text { Pachytenes } \\
(\%)\end{array}$ & $\begin{array}{c}\text { Round } \\
\text { Spermatids } \\
(\%)\end{array}$ & $\begin{array}{l}\text { Sertoli Cells } \\
(\%)\end{array}$ & $\operatorname{SSR}^{\mathrm{a}}$ \\
\hline PG1 & $17.36 \pm 12.70$ & $22.63 \pm 10.49$ & $9.61 \pm 4.30$ & $10.53 \pm 2.75$ & $21.45 \pm 12.34$ & $18.42 \pm 2.91$ & 2.03 \\
\hline PG2 & $6.34 \pm 2.20$ & $12.67 \pm 7.08$ & $21.42 \pm 22.00$ & $16.16 \pm 5.81$ & $33.40 \pm 15.23$ & $10.01 \pm 2.46$ & 2.06 \\
\hline PG3 & $11.03 \pm 7.98$ & $12.76 \pm 7.44$ & $16.77 \pm 31.65$ & $14.54 \pm 14.46$ & $33.36 \pm 23.08$ & $11.53 \pm 4.00$ & 2.29 \\
\hline PN1 & $15.61 \pm 4.69$ & $13.33 \pm 6.81$ & $22.28 \pm 10.90$ & $15.70 \pm 4.43$ & $23.86 \pm 14.72$ & $9.22 \pm 1.43$ & 1.50 \\
\hline PN2 & $9.42 \pm 7.04$ & $8.22 \pm 2.45$ & $16.38 \pm 13.49$ & $10.47 \pm 5.72$ & $43.95 \pm 20.33$ & $11.56 \pm 4.12$ & 4.19 \\
\hline $\mathrm{H} 1$ & $41.64 \pm 4.55$ & $29.79 \pm 2.39$ & $9.42 \pm 0.00$ & 0.00 & 0.00 & $19.15 \pm 3.65$ & 0.00 \\
\hline $\mathrm{H} 2$ & $15.52 \pm 3.39$ & $15.64 \pm 6.82$ & $22.79 \pm 8.36$ & $18.18 \pm 5.23$ & $15.27 \pm 6.17$ & $12.60 \pm 2.01$ & 0,84 \\
\hline
\end{tabular}

${ }^{\text {a }}$ Spermatid-to-spermatocyte ratio.

Table 4. Seminal parameters of adult bucks of M. gouazoubira, M. nemorivaga, and inter-specific hybrids.

\begin{tabular}{|c|c|c|c|c|c|c|c|c|}
\hline \multirow{2}{*}{ Animal } & \multirow{2}{*}{ Volume $(\mu \mathrm{L})$} & \multirow{2}{*}{$\begin{array}{c}\text { Concentration } \\
\left(10^{9} / \mathrm{mL}\right)\end{array}$} & \multirow{2}{*}{ Color } & \multirow{2}{*}{ Motility (\%) } & \multirow{2}{*}{ Vigor (0-5) } & \multicolumn{2}{|c|}{ Defects (\%) } & \multirow{2}{*}{$\begin{array}{c}\text { Normal } \\
\text { Sperm (\%) }\end{array}$} \\
\hline & & & & & & Primary & Secondary & \\
\hline PG1 & 375 & 0.57 & White & 40 & 2 & 37.0 & 5.0 & 58.0 \\
\hline PG2 & 240 & 3.34 & White & 65 & 4 & 29.5 & 13.5 & 57.0 \\
\hline PG3 & 270 & 2.32 & White & 60 & 3 & 13.5 & 13.0 & 73.0 \\
\hline PN1 & 375 & 2.25 & Reddish $^{\text {a }}$ & 70 & 3 & 35.0 & 13.5 & 51.5 \\
\hline PN2 & 60 & 2.71 & Reddish $^{\text {a }}$ & 90 & 4 & 4.0 & 39.0 & 57.0 \\
\hline $\mathrm{H} 1^{b}$ & 160 & - & Clear & - & - & - & - & - \\
\hline $\mathrm{H} 2$ & 50 & 0.02 & Watery & $<1$ & 0 & 66.0 & 24.0 & 10.0 \\
\hline
\end{tabular}

${ }^{a}$ Considered physiologically normal for the species [39]. ${ }^{\mathrm{b}}$ Azoospermic. 


\subsection{Intra-Specific Hybrids}

FISH with bovine BAC probes specific to the chromosomes involved in translocations was used to assess the fertility of heterozygous and homozygous translocation carriers in MAM. A total of 5000 and 2000 sperm nuclei were scored for RT and TF carriers, respectively. The sperm-FISH technique showed high specificity and sensitivity in red brocket deer sperm nuclei with bovine BAC probes hybridization rates higher than $99 \%$ in all cases. Results obtained for the RT and TF are presented in Tables 5 and 6 and summarized below.

Table 5. Sperm meiotic segregation in Robertsonian translocation carriers of Mazama americana, including a non-translocated buck as control.

\begin{tabular}{|c|c|c|c|c|c|c|c|c|}
\hline \multirow{3}{*}{$\begin{array}{l}\text { FISH Phenotype } \\
\text { Normal/Balanced }\end{array}$} & \multicolumn{8}{|c|}{ Robertsonian Translocation (A;B) (\%) } \\
\hline & \multicolumn{2}{|c|}{$\mathrm{T} 269 \operatorname{rob}(7 ; 20)^{a, d}$} & \multicolumn{2}{|c|}{$\mathrm{T} 274 \operatorname{rob}(5 ; 11)^{a, e}$} & \multicolumn{2}{|c|}{$T 326 \operatorname{rob}(5 ; 11)^{b, e}$} & \multicolumn{2}{|c|}{ T297 c,e } \\
\hline & 4890 & $(97.80)$ & 4884 & $(97.68)$ & 4949 & $(98.98)$ & 4926 & $(98.52)$ \\
\hline Nullisomy A & 36 & $(0.72)$ & 21 & $(0.42)$ & 18 & $(0.36)$ & 19 & $(0.38)$ \\
\hline Disomy A & 7 & $(0.14)$ & 10 & $(0.20)$ & 6 & $(0.12)$ & 3 & $(0.06)$ \\
\hline Nullisomy B & 25 & $(0.50)$ & 33 & $(0.66)$ & 8 & $(0.16)$ & 17 & $(0.34)$ \\
\hline Disomy B & 29 & $(0.58)$ & 19 & $(0.38)$ & 7 & $(0.14)$ & 7 & $(0.14)$ \\
\hline Total adjacent & 97 & $(1.94)$ & 83 & $(1.66)$ & 39 & $(0.78)$ & 46 & $(0.92)$ \\
\hline Disomy A + B & 1 & $(0.02)$ & 9 & $(0.18)$ & 0 & $(0.00)$ & 7 & $(0.14)$ \\
\hline Nullisomy A + B & 1 & $(0.02)$ & 9 & $(0.18)$ & 6 & $(0.12)$ & 2 & $(0.04)$ \\
\hline Diploidy & 7 & $(0.14)$ & 10 & $(0.20)$ & 5 & $(0.10)$ & 19 & $(0.38)$ \\
\hline Others ${ }^{f}$ & 4 & $(0.08)$ & 5 & $(0.10)$ & 1 & $(0.02)$ & 0 & $(0.00)$ \\
\hline Total unbalanced & 110 & $(2.20)$ & 116 & $(2.32)$ & 51 & $(1.02)$ & 74 & $(1.48)$ \\
\hline TOTAL & 5000 & $(100)$ & 5000 & $(100)$ & 5000 & $(100)$ & 5000 & $(100)$ \\
\hline
\end{tabular}

${ }^{a}$ Heterozygous carrier. ${ }^{b}$ Homozygous carrier. ${ }^{c}$ Non-translocated buck (normal karyotype). ${ }^{d}$ Buck analyzed with bovine BAC probes $17 C$ and BAC 25M. ${ }^{\text {e }}$ Buck analyzed with bovine BAC probes $13 \mathrm{~T}$ and $19 \mathrm{~T} .{ }^{\mathrm{f}}$ Other, less frequent signal combinations.

Table 6. Sperm meiotic segregation in heterozygous tandem fusion carrier hybrids of Mazama americana cytotypes, including a non-translocated buck as control.

\begin{tabular}{|c|c|c|c|c|c|c|c|c|}
\hline \multirow{3}{*}{$\begin{array}{l}\text { FISH Phenotype } \\
\text { Normal/Balanced }\end{array}$} & \multicolumn{8}{|c|}{ Tandem Fusion $(\mathrm{A} ; \mathrm{B})(\%)$} \\
\hline & \multicolumn{2}{|c|}{ T343 der $(7 ; 10)^{a}$} & \multicolumn{2}{|c|}{ T347 der $(7 ; 10)^{a}$} & \multicolumn{2}{|c|}{ T421 der $(5 ; 10)^{b}$} & \multicolumn{2}{|c|}{$\mathrm{T} 297^{\mathrm{b}, \mathrm{c}}$} \\
\hline & 1139 & $(56.95)$ & 1390 & $(69.50)$ & 1505 & $(75.25)$ & 1970 & $(98.50)$ \\
\hline Nullisomy A & 328 & $(16.40)$ & 203 & $(10.15)$ & 166 & $(8.30)$ & 6 & $(0.30)$ \\
\hline Disomy A & 249 & (12.45) & 170 & $(8.50)$ & 144 & (7.20) & 5 & $(0.25)$ \\
\hline Nullisomy B & 124 & $(6.20)$ & 109 & $(5.45)$ & 56 & $(2.80)$ & 8 & $(0.40)$ \\
\hline Disomy B & 82 & $(4.10)$ & 67 & (3.35) & 46 & $(2.30)$ & 4 & $(0.20)$ \\
\hline Total adjacent & 783 & $(39.15)$ & 549 & $(27.45)$ & 412 & $(20.60)$ & 23 & $(1.15)$ \\
\hline Disomy A + B & 18 & $(0.90)$ & 13 & $(0.65)$ & 26 & $(1.30)$ & 4 & $(0.20)$ \\
\hline Nullisomy A + B & 11 & $(0.55)$ & 12 & $(0.60)$ & 11 & $(0.55)$ & 3 & $(0.15)$ \\
\hline Diploidy & 15 & $(0.75)$ & 11 & $(0.55)$ & 12 & $(0.60)$ & 0 & $(0.00)$ \\
\hline Others $d$ & 34 & $(1.70)$ & 25 & $(1.25)$ & 34 & $(1.70)$ & 0 & $(0.00)$ \\
\hline Total unbalanced & 861 & $(43.05)$ & 610 & $(30.50)$ & 495 & $(24.75)$ & 30 & $(1.50)$ \\
\hline TOTAL & 2000 & $(100)$ & 2000 & $(100)$ & 2000 & $(100)$ & 2000 & $(100)$ \\
\hline
\end{tabular}

${ }^{\mathrm{a}}$ Buck analyzed with bovine BAC probes $2 \mathrm{P}$ and BAC $19 \mathrm{~T} .{ }^{\mathrm{b}}$ Buck analyzed with bovine BAC probes $3 \mathrm{~T}$ and $28 \mathrm{M} .{ }^{\mathrm{c}}$ Non-translocated buck (normal karyotype). ${ }^{\mathrm{d}}$ Other, less frequent signal combinations.

Regarding the RT carriers, the meiotic segregation patterns were not significantly different among the homozygous and heterozygous carriers and the control (Table 5). No significant differences were observed between the frequencies of nullisomies and disomies for any one of the analyzed chromosomes). 
Regarding the heterozygous TF carriers, their segregation profiles (Table 6) were noticeably different when compared to RT cases described above. The MAM hybrids with heterozygous TFs showed lower rates of normal/balanced spermatozoa with a mean frequency of $67.23 \%$, as well as higher rates of adjacent products with a mean frequency of $29.07 \%$. Frequencies of nullisomies and disomies were not different for any one of the chromosomes. Hybrid T343 also shared the same RT presented for the Rondônia cytotype $\operatorname{rob}(7 ; 20)$, inherited from its mother.

\section{Discussion}

Several studies on chromosomal polymorphism point out its key role in the formation of gene flow barriers between populations or species and, consequently, in the processes of adaptation and speciation [1-3]. In this context, the presence of chromosome heterozygosity is considered the main factor responsible for the formation of these barriers. Thus, a reduction in the reproductive fitness of the carriers might be caused by a hypothetical probability of errors in meiotic segregation and the formation of unbalanced gametes [1,2]. However, the real impact of these chromosomal rearrangements on the reproductive fitness of carriers and their subsequent impact within a population is not always fully understood. This knowledge gap worsens in wild species, where studies on the topic are scarce when compared to reports in domestic species [27,40-45].

Regarding the family Cervidae, the occurrence of chromosomal polymorphisms has been reported throughout the karyotype evolution of several species [7,8]. It is assumed that the ancestral karyotype of this family had 34 pairs of acrocentric autosomes, an acrocentric $X$, and a small submetacentric $Y(2 n=70 ; F N=70)$, given its presence in two species with long phylogenetic distance, such as Hidropotes inermis (Old world deer) and $M$. gouazoubira (New world deer) $[5,7,8]$. Thus, the karyotype evolution in the different genera of the family has been developed mainly by the reduction of the diploid number and the accumulation of chromosomal rearrangements such as inversions, RT or TF, as observed in the evolutionary history of the genus Mazama [7-11,46,47].

Hybridization evaluation between species or nearby lineages is one of the best approaches for those seeking to understand the diversification process [48]. In this study, we investigated the effect of chromosomal rearrangements on the fertility of hybrids between cytotypes of the same lineage (MAM) and between different species (MGO $\times$ MNE), to determine how these chromosomal polymorphisms could act as an effective barrier to genetic flow during parapatric or sympatric speciation in the genus Mazama.

\subsection{Inter-Specific Hybrids}

The sterility observed in hybrid animals is a way to irreversibly accelerate genetic divergences, preventing free gene flow between genetically different populations [49]. Traditionally, hybrid sterility is attributed to genetic incompatibilities between parental species, whether of chromosomal or genetic origin [50]. Although in most animals, incompatibilities mediated by deleterious interactions between genes are considered the primary cause of hybrid inaptitude (Dobzhansky-Müller model). The results of cytogenetic analyzes of the MGO $\times$ MNE hybrids most likely indicate that the occurrence of post-zygotic reproductive isolation between MGO and MNE is probably linked to numerical and structural chromosomal differences. These differences lead to the accumulation of heterozygous chromosomal rearrangements in the hybrids and may trigger anomalous pairing during meiosis, resulting in gametogenesis failures and unbalanced gamete production [51].

Even though inter-individual variation among animals was evident, in general, all seminal, morphological, and most histological reproductive parameters observed in pure animals (PG1, PG2, PG3, PN1, and PN2) were superior to those obtained for hybrids, being within expected for their respective species [39,52]. In contrast, evidence of fertility reduction varied between the hybrids, showing different effects of chromosomal differences found between the parent's karyotypes. 
The effect of the chromosomal rearrangements accumulation on hybrid reproductive fitness was especially evident in $\mathrm{H} 1$, with a rob(4;32) and a submetacentric $\mathrm{X}$ inherited from the mother (MNE). In its spermiogram, this animal demonstrated complete interruption of spermatogenesis, which was reflected in azoospermia. In this case, presumed sterility could be attributed to multiple chromosomal pairing failures during meiosis, getting worse when differences between parent karyotypes are greater [53]. Thus, the H1 karyotype ( $2 \mathrm{n}=69+0-3 \mathrm{Bs})$ was the most discrepant concerning the pattern of parental species among the analyzed MGO $\times$ MNE hybrids.

In most cases of hybrid sterility, associations between cell death and meiosis occur between pachytene and spermiogenesis, which results in high attrition rates in the pachytene of meiosis I [54]. Similar patterns in the histological analysis of H1 cell types suggested spermatogenic interruption. Moreover, the total hypoplasia of seminiferous tubules observed in H1, frequently described in infertile hybrids [55-57], is a direct consequence of the spermatogenesis interruption during meiosis I. The absence of differentiated germ cells results in a decrease in tubular diameter and height of seminiferous epithelium, aspects that in H1, obtained the lowest averages among all animals analyzed. Similar conformations have been reported in other hybrid forms such as donkeys [58], rats [57], and within the MAM cytotype complex itself [25].

Despite having obtained better performance than $\mathrm{H} 1$ in all reproductive analyzes, mostly functional tubular structure, and no chromosomal translocation, the fertility of the $\mathrm{H} 2$ hybrid was also severely affected by chromosomal differences. The severe subfertility showed by $\mathrm{H} 2$ reinforces the importance of the role of chromosomes in the process of reproductive isolation, even when the rearrangements are not so apparent. Seminal analysis of this animal revealed an ejaculate with extremely low volume and concentration, irrelevant motility, and a high prevalence of sperm defects. This low seminal quality is the result of a series of structural, pathological, and functional changes at the testicular level: $\mathrm{H} 2$ showed hypoplasia in part of its seminiferous tubules and the presence of cells with a pycnotic nucleus and epithelial vacuolization, suggestive of the occurrence of apoptosis in both functional and hypoplastic tubules. Moreover, $\mathrm{H} 2$ also showed a low conversion rate between spermatids and spermatocytes $(S R R=0.84)$ when compared with pure animals. All of this evidence points to the loss of germinal epithelium and cell degeneration, typically found in hybrid forms [57,59].

Finally, it is worth remembering that although the presence of sperm in a hybrid ejaculate has been described in several inter-specific crossbreeding [55,59-62], it does not guarantee its fertility. Chromosomal non-disjunction during anaphase I is the second leading cause of reduced fertility in these animals since heterozygous configurations of hybrids undergo an anomalous separation process leading to the formation of unbalanced gametes (aneuploidy) and non-viable embryos [59]. Thus, it is likely that, similar to what was observed in intra-specific MAM hybrids in this study, future FISH analysis of $\mathrm{H} 2$ also reveals a high rate of unbalanced gametes.

Since the pre-zygotic reproductive barrier between MNE and MGO is fragile [63], the post-zygotic barrier for sterility of the hybrid seems to keep these two species isolated and evolving independently. Even with wide geographical contact between the Amazon (MNE habitat) and the Cerrado (MGO habitat) for more than $2000 \mathrm{~km}$.

\subsection{Intra-Specific Hybrids}

A previous study carried out in MAM, demonstrated that hybrids with the presence of heterozygous TF presented seminal parameters similar to those presented by pure animals of the different lineages (volume: $270 \mu \mathrm{L}$ vs. $135 \mu \mathrm{L}$; motility: $75 \%$ vs. $77.5 \%$; concentration: $2.22 \mathrm{sptz} \times 10^{9} / \mathrm{mL}$ vs. $3.81 \mathrm{sptz} \times 10^{9} / \mathrm{mL}$; and pathologies: $47.25 \%$ vs. $30 \%$, for heterozygous TF hybrids and pure animals, respectively) [25]. Thus, the fertility of the hybrids could not be defined or ruled out, which is why they were considered subfertile. Because of this, we decided to perform the technique of sperm-FISH to estimate the proportion of normal/balanced and unbalanced spermatozoa in bucks with heterozygous 
rearrangements and animals from crossbreeding between cytotypes of the same lineage in MAM. The proportion of meiotic products from adjacent segregation modes in RT carriers analyzed in this study is consistent with reports for domestic species such as bulls, boars and mice $(2.58-5.42 \%, 3.16 \%$, and $8-11.5 \%$, respectively) [64-67]. These findings may suggest a low negative effect on the reproductive fitness of heterozygous carriers of RT reported here for MAM, unlike that reported for several RT in humans where there is a wide variation in reproductive impact (0.2-49.1\% of adjacent segregation products) [68].

Our results are in agreement with a previous report focused on the synaptonemal complex analysis of the same heterozygous $\operatorname{rob}(7 ; 20)$ carrier (T269) [27], where results suggested a highly unlikely formation of unbalanced gametes for this RT. Similar results for synaptonemal complex analysis focused on the effect of centromeric fusion on meiosis and reproduction of cattle, goitered gazelle, and impala have been reported $[40,69,70]$. In fact, the NUPECCE's breeding records indicate that this rob(7;20) carrier was used for breeding purposes and produced 4 fawns, not exhibiting any obvious reproductive impairment. Regarding the rob(5;11), the heterozygous carrier produced a non-translocated female fawn, also suggesting no reproductive impairment. On the other hand, no reproductive records were available for the homozygous carrier. However, our findings suggest that the homozygous translocation could offer greater stability during the meiotic segregation, not affecting its reproductive fitness, and showing a meiotic segregation pattern similar to the control values. The presence of homozygous translocation suggests a possible fixation of this chromosomal polymorphism in free-living populations, opening the possibility of future speciation processes. However, our results on the meiotic segregation patterns of carriers, both homozygous and heterozygous rob(5;11), would suggest an apparent gene flow between these populations. Thus, every single RT must be assessed to understand its potential effect on the reproductive fitness of the carriers. Errors in meiosis are the result of the behavior of those chromosomes involved in the translocation and their trivalent during the first meiotic segregation. [40,68].

In this study, we also analyzed three heterozygous TF carriers produced in captivity between Mazama americana cytotypes of the same chromosomal lineage $(n=2$, Rondônia $\times$ Juína cytotypes; $n=1$, Carajás $\times$ Paraná cytotypes) [10]. Although TF are chromosomal rearrangements present in the evolutionary history of cervids, they have been previously related with reduction in fertility in animal [71-73]. A previous study reported subfertile male hybrids from MAM cytotypes of the same chromosomal lineage and azoospermic hybrids from different chromosomal lineages [25]. Azoospermia was attributed to the great karyotypic differences, a meiotic arrest in spermatocyte stage, and errors in meiotic segregation for hybrids between different lineages, providing an adequate post-zygotic reproductive barrier and suggesting the presence of different species [25]. In this study, MAM hybrids heterozygous for TF showed the highest rate of unbalanced spermatozoa of all analyzed Mazama males. This can explain the previously reported subfertility of Rondônia $\times$ Juína hybrids, carrying a heterozygous TF, which did not show any significant compromise in seminal quality or testicular histology [25].

Also, it is important to mention that hybrid T343 also carried a heterozygous rob(7;20), which might have increased the errors in meiotic chromosome pairing, leading to a greater error in meiotic segregation in this buck. Thus, the red brocket male T269 only heterozygous for the $\operatorname{rob}(7 ; 20)$, or hybrid T347 only heterozygous for the der(7;10), showed unbalanced spermatozoa rates of 2.20 and 30.50\%, respectively. Regarding hybrids T347 and T421, our data presented about $70 \%$ balanced gametes suggesting a subfertility status, similar to Salviano et al. (2017) and contrasting the estimates of 50\% aneuploid gametes made by White et al. (1967) [74] for heterozygous TF. However, if we consider a hypothetical 1:1 ratio between gametes carrying or not the $\mathrm{TF}$, we would have a frequency of $35 \%$ for each phenotype. This will be, only a $35 \%$ chance of successful reproduction in a backcross of the T347 hybrid with a female of cytotype Rondônia or Juína, and the T421 hybrid with a female of cytotype Carajás or Paraná, suggesting virtual sterility of the hybrids similar to 
the Otomys irroratus case [73], and dismissing the previous description of subfertility for hybrids carrying heterozygous TF in MAM, made by Salviano et al. (2017) [25].

We report the first production of hybrids between MGO and MNE, which were viable until maturity, but presumably infertile. There are no reports of hybrids in the wild, although a weak pre-mating isolation barrier between species has been observed in captivity [63]. Regarding MAM, reports of captive crossbreeding between cytotypes already exist $[25,75]$, which are explained by the verified lack of a clear pre-mating barrier [26]. However, it is difficult to say that this can happen in nature, despite the geographical proximity between MGO and MNE, as well as between the MAM cytotypes. Therefore, there is a clear need for a better understanding of chromosomal polymorphisms between species and intra-specific populations to elucidate their role in forming barriers to gene flow within the genus Mazama, the isolation from former populations, and subsequent adaptation/speciation. Moreover, meiotic segregation assessment in hybrids and carriers of heterozygous chromosomal translocations is presented as a mandatory tool for estimating the impact of chromosomal polymorphisms in both the reproductive fitness of carriers and in Mazama speciation processes. Thus, leaving the morphological evaluation of the gametes as a complementary assessment.

Supplementary Materials: The following are available online at https:/ /www.mdpi.com/2073-442 5/12/2/165/s1, Table S1: List of bovine BAC clones used in the present study for detection of bovine (Bos Taurus-BTA) homologies with brocket deer chromosomes involved in translocations and for sperm-FISH.

Author Contributions: Conceptualization, D.J.G. and J.M.B.D.; Investigation, D.J.G., G.S.M., M.V., H.C., S.K., A.M.B., and D.K.; Methodology, M.V., H.C., S.K., and J.M.B.D.; Formal analysis, D.J.G. and G.S.M.; Funding acquisition, D.J.G., M.V., and J.M.B.D.; Resources, J.M.B.D.; Supervision, J.R. and J.M.B.D.; Visualization, D.J.G. and G.S.M.; Writing—original draft, D.J.G. and G.S.M.; Writingreview \& editing, M.V., J.R., and J.M.B.D. All authors have read and agreed to the published version of the manuscript.

Funding: This research was funded by the São Paulo Research Foundation (FAPESP, Regular Research Grant 2010/50748-3, 2017/07014-8 and 2019/06940-1), the Czech Science Foundation (GACR, grant 20-22517J), Ministry of Agriculture of the Czech Republic, grant No. RO 0520, and Ministry of Education, Youth and Sports of the Czech Republic under the project CEITEC 2020 (grant LQ1601). Galindo DJ was supported by the National Fund for Scientific, Technological, and Technological Innovation Development (FONDECYT), the funding branch of the National Council for Science, Technological, and Technological Innovation Development (CONCYTEC) Peru (Grant Contract No. 116-2017-FONDECYT). Duarte JMB had financial support from CNPq/Brazil.

Institutional Review Board Statement: The study was conducted according to the guidelines of the Declaration of Helsinki, and approved by the Ethics Committee on Animal Use of the School of Agricultural and Veterinarian Sciences, São Paulo State University (approval No. 000180/11 and 001930/18). The biological material for tissue culture, semen analysis and testicular histology was obtained by a veterinarian during medical examination of the animals.

Informed Consent Statement: Not applicable.

Data Availability Statement: The data presented in this study are available in the article and supplementary material.

Acknowledgments: The authors wish to thank to the whole NUPECCE team for their collaborative support.

Conflicts of Interest: The authors declare no conflict of interest. The funders had no role in the design of the study; in the collection, analyses, or interpretation of data; in the writing of the manuscript, or in the decision to publish the results.

\section{References}

1. Dobigny, G.; Britton-Davidian, J.; Robinson, T.J. Chromosomal polymorphism in mammals: An evolutionary perspective. Biol. Rev. Camb. Philos. Soc. 2017, 92, 1-21. [CrossRef] [PubMed] 
2. Faria, R.; Navarro, A. Chromosomal speciation revisited: Rearranging theory with pieces of evidence. Trends Ecol. Evol. 2010, 25, 660-669. [CrossRef] [PubMed]

3. Farré, M.; Micheletti, D.; Ruiz-Herrera, A. Recombination rates and genomic shuffling in human and chimpanzee-a new twist in the chromosomal speciation theory. Mol. Biol. Evol. 2013, 30, 853-864. [CrossRef] [PubMed]

4. Yang, F.; O'Brien, P.C.M.; Wienberg, J.; Ferguson-Smith, M.A. A reappraisal of the tandem fusion theory of karyotype evolution in Indian muntjac using chromosome painting. Chromosome Res. 1997, 5, 109-117. [CrossRef]

5. Yang, F.; O'Brien, P.C.M.; Wienberg, J.; Neitzel, H.; Lin, C.C.; Ferguson-Smith, M.A. Chromosomal evolution of the Chinese muntjac (Muntiacus reevesi). Chromosoma 1997, 106, 37-43. [CrossRef]

6. Duarte, J.M.B.; Jorge, W. Morphologic and Cytogenetic Description of the Small Red Brocket (Mazama bororo Duarte,1996) in Brazil. Mammalia 2003, 67, 403-410. [CrossRef]

7. Neitzel, H. Chromosome Evolution of Cervidae: Karyotypic and Molecular Aspects. In Cytogenetics-Basic and Applied Aspects; Obe, G., Basler, A., Eds.; Springer: Berlin/Heidelberg, Germany, 1987; pp. 90-112. ISBN 978-3-642-728004-4.

8. Fontana, F.; Rubini, M. Chromosomal evolution in cervidae. BioSystems 1990, 24, 157-174. [CrossRef]

9. Abril, V.V.; Duarte, J.M.B. Chromosome polymorphism in the Brazilian dwarf brocket deer, Mazama nana (Mammalia, Cervidae). Genet. Mol. Biol. 2008, 31, 53-57. [CrossRef]

10. Abril, V.V.; Carnelossi, E.A.G.; González, S.; Duarte, J.M.B. Elucidating the Evolution of the Red Brocket Deer Mazama americana Complex (Artiodactyla; Cervidae). Cytogenet. Genome Res. 2010, 128, 177-187. [CrossRef]

11. Fiorillo, B.F.; Sarria-Perea, J.A.; Abril, V.V.; Duarte, J.M.B. Cytogenetic description of the Amazonian brown brocket Mazama nemorivaga (Artiodactyla, Cervidae). Comp. Cytogenet. 2013, 7, 25-31. [CrossRef]

12. Valeri, M.P.; Tomazella, I.M.; Duarte, J.M.B. Intrapopulation Chromosomal Polymorphism in Mazama gouazoubira (Cetartiodactyla; Cervidae): The Emergence of a New Species? Cytogenet. Genome Res. 2018, 154, 147-152. [CrossRef] [PubMed]

13. Tomazella, I.M. Análise de Polimorfismo Cromossômico em Mazama Gouazoubira (Artiodactyla; Cervidae): Implicações Para a Evolução Cariotípica em Cervidae; Universidade Estadual Paulista: Ilha Solteira, Brazil, 2016.

14. Vargas-Munar, D.S.F.; Sarria-Perea, J.A.; Duarte, J.M.B. Different responses to doxorubicin-induced chromosome aberrations in Brazilian deer species. Genet. Mol. Res. 2010, 9, 1545-1549. [CrossRef] [PubMed]

15. Tomazella, I.M.; Abril, V.V.; Duarte, J.M.B. Identifying Mazama gouazoubira (Artiodactyla; Cervidae) chromosomes involved in rearrangements induced by doxorubicin. Genet. Mol. Biol. 2017, 40, 460-467. [CrossRef] [PubMed]

16. Duarte, J.M.B.; González, S.; Maldonado, J.E. The surprising evolutionary history of South American deer. Mol. Phylogenet. Evol. 2008, 49, 17-22. [CrossRef] [PubMed]

17. González, S.; Barbanti Duarte, J.M. Speciation, evolutionary history and conservation trends of Neotropical deer. Mastozoología Neotrop. 2020, 27, 35-46. [CrossRef]

18. IUCN. The IUCN Red List of Threatened Species. Version 2020-2. Available online: https://www.iucnredlist.org/ (accessed on 24 July 2020).

19. Rossi, R.V. Taxonomia de Mazama RAFINESQUE, 1817, do Brasil (Artiodactyla, Cervidae); Universidade de São Paulo: São Paulo, Brazil, 2000.

20. Morales-Donoso, J.A. Caracterização Morfológica, Citogenética e Molecular de Mazama Nemorivaga (Cuvier, 1817) a Partir de um Topótipo Atual; Universidade Estadual Paulista: Ilha Solteira, Brazil, 2017.

21. Duarte, J.M.B.; Merino, M.L. Taxonomia e Evolução. In Biologia e Conservação de Cervídeos Sul-Americanos: Blastocerus, Ozotoceros e Mazama; Duarte, J.M.B., Ed.; FUNEP: Jaboticabal, Brazil, 1997; pp. 1-21.

22. Figueiredo, M.G. Filogenia e Taxonomia dos Veados Cinza (Mazama gouazoubira e M. nemorivaga); Universidade Estadual Paulista: Ilha Solteira, Brazil, 2014.

23. Resende, J.P.d.A. Comparação Cariotípica Entre Mazama Gouazoubira e Mazama Nemorivaga (Artiodactyla; Cervidae) por Meio de Marcadores Citogenéticos Clássicos, Fish Telomérica e Pintura Cromossômica; Universidade Estadual Paulista: Ilha Solteira, Brazil, 2012.

24. King, M. Species Evolution The Role of Chromosome Change; Cambridge University Press: Cambridge, UK, 1993 ; ISBN 9780521484541.

25. Salviano, M.B.; Cursino, M.S.; Zanetti, E.S.; Abril, V.V.; Duarte, J.M.B. Intraspecific chromosome polymorphisms can lead to reproductive isolation and speciation: An example in red brocket deer (Mazama americana). Biol. Reprod. 2017, 96, 1279-1287. [CrossRef]

26. Carranza, J.; Roldán, M.; Duarte, J.M.B. Lack of mate selectivity for genetic compatibility within the red brocket deer Mazama americana complex. Mamm. Biol. 2018, 88, 168-175. [CrossRef]

27. Aquino, C.I.; Abril, V.V.; Duarte, J.M.B. Meiotic pairing of B chromosomes, multiple sexual system, and Robertsonian fusion in the red brocket deer Mazama americana (Mammalia, Cervidae). Genet. Mol. Res. 2013, 12, 3566-3574. [CrossRef]

28. Abril, V.V. Evolução Cromossômica no Veado-Mateiro-Mazama Americana (Mammalia; Cervidae); Universidade Estadual Paulista: Ilha Solteira, Brazil, 2009.

29. Fröhlich, J.; Kubickova, S.; Musilova, P.; Cernohorska, H.; Muskova, H.; Rubes, J. A Comparative Study of Pygmy Hippopotamus (Choeropsis liberiensis) Karyotype by Cross-Species Chromosome Painting. J. Mamm. Evol. 2017, 24, 465-474. [CrossRef]

30. Kubickova, S.; Cernohorska, H.; Musilova, P.; Rubes, J. The use of laser microdissection for the preparation of chromosome-specific painting probes in farm animals. Chromosome Res. 2002, 10, 571-577. [CrossRef] 
31. Telenius, H.; Carter, N.P.; Bebb, C.E.; Nordenskjöld, M.; Ponder, B.A.J.; Tunnacliffe, A. Degenerate oligonucleotide-primed PCR: General amplification of target DNA by a single degenerate primer. Genomics 1992, 13, 718-725. [CrossRef]

32. Vozdova, M.; Kubickova, S.; Cernohorska, H.; Fröhlich, J.; Vodicka, R.; Rubes, J. Comparative Study of the Bush Dog (Speothos venaticus) Karyotype and Analysis of Satellite DNA Sequences and Their Chromosome Distribution in Six Species of Canidae. Cytogenet. Genome Res. 2019, 159, 88-96. [CrossRef] [PubMed]

33. Favoretto, S.M.; Zanetti, E.S.; Duarte, J.M.B. Cryopreservation of red brocket deer semen (Mazama americana): Comparison between three extenders. J. Zoo Wildl. Med. 2012, 43, 820-827. [CrossRef] [PubMed]

34. Duarte, J.M.B.; Garcia, J.M. Assistant Reproduction in Brazilian Cervidae. Rev. Bras. Reprod. Anim. 1995, 19, 111-121.

35. Alvarez, M.C.L.; Rola, L.D.; Duarte, J.M.B. Comparison Between Three Cryoprotectants in the Freezing of Mazama americana Semen Collected by Artificial Vagina. Biopreserv. Biobank. 2020. [CrossRef] [PubMed]

36. BLOM, E. Interpretation of spermatic cytology in bulls. Fertil. Steril. 1950, 1, 223-238. [CrossRef]

37. Rubes, J.; Vozdová, M.; Kubícková, S. Aneuploidy in pig sperm: Multicolor fluorescence in situ hybridization using probes for chromosomes 1, 10, and Y. Cytogenet. Cell Genet. 1999, 85, 200-204. [CrossRef] [PubMed]

38. R Core Team. R: A Lenguage and Environment for Statistical Computing; R Foundation for Statistical Computing: Vienna, Austria, 2020.

39. Cursino, M.S.; Duarte, J.M.B. Using sperm morphometry and multivariate analysis to differentiate species of gray Mazama. $R$. Soc. Open Sci. 2016, 3, 1-9. [CrossRef]

40. Vozdova, M.; Sebestova, H.; Kubickova, S.; Cernohorska, H.; Awadova, T.; Vahala, J.; Rubes, J. Impact of Robertsonian translocation on meiosis and reproduction: An impala (Aepyceros melampus) model. J. Appl. Genet. 2014, 55, 249-258. [CrossRef]

41. Pinton, A.; Faraut, T.; Yerle, M.; Gruand, J.; Pellestor, F.; Ducos, A. Comparison of male and female meiotic segregation patterns in translocation heterozygotes: A case study in an animal model (Sus scrofa domestica L.). Hum. Reprod. 2005, 20, 2476-2482. [CrossRef]

42. Bonnet-Garnier, A.; Lacaze, S.; Beckers, J.F.; Berland, H.M.; Pinton, A.; Yerle, M.; Ducos, A. Meiotic segregation analysis in cows carrying the $\mathrm{t}(1 ; 29)$ Robertsonian translocation. Cytogenet. Genome Res. 2008, 120, 91-96. [CrossRef] [PubMed]

43. Massip, K.; Yerle, M.; Billon, Y.; Ferchaud, S.; Bonnet, N.; Calgaro, A.; Mary, N.; Dudez, A.-M.; Sentenac, C.; Plard, C.; et al. Studies of male and female meiosis in inv(4)(p1.4;q2.3) pig carriers. Chromosom. Res. 2010, 18, 925-938. [CrossRef] [PubMed]

44. Zackowski, J.L.; Martin-DeLeon, P.A. Segregation products of male mice doubly heterozygous for the RB(6.16) and RB(16.17) translocations: Influence of sperm karyotype on fertilizing competence under varying mating frequencies. Gamete Res. 1989, 22, 93-107. [CrossRef] [PubMed]

45. Sánchez-Sánchez, R.; Gómez-Fidalgo, E.; Pérez-Garnelo, S.; Martín-Lluch, M.; De la Cruz-Vigo, P. Prevalence of chromosomal aberrations in breeding pigs in Spain. Reprod. Domest. Anim. 2019, 54, 98-101. [CrossRef] [PubMed]

46. Yang, F.; Carter, N.P.; Shi, L.; Ferguson-Smith, M.A. A comparative study of karyotypes of muntjacs by chromosome painting. Chromosoma 1995, 103, 642-652. [CrossRef]

47. Duarte, J.M.B.; Jorge, W. Chromosomal polymorphism in several populations of deer (Genus Mazama) from Brazil. Arch. Zootec. 1996, 45, 281-287.

48. Grize, S.A.; Wilwert, E.; Searle, J.B.; Lindholm, A.K. Measurements of hybrid fertility and a test of mate preference for two house mouse races with massive chromosomal divergence. BMC Evol. Biol. 2019, 19, 25. [CrossRef]

49. Oka, A.; Mita, A.; Takada, Y.; Koseki, H.; Shiroishi, T. Reproductive isolation in hybrid mice due to spermatogenesis defects at three meiotic stages. Genetics 2010, 186, 339-351. [CrossRef]

50. Li, X.C.; Barringer, B.C.; Barbash, D.A. The pachytene checkpoint and its relationship to evolutionary patterns of polyploidization and hybrid sterility. Heredity 2009, 102, 24-30. [CrossRef]

51. Switoński, M.; Stranzinger, G. Studies of synaptonemal complexes in farm mammals-A review. J. Hered. 1998, 89, 473-480. [CrossRef]

52. Barrozo, L.A.; Toniolo, G.H.; Duarte, J.M.B.; Pinho, M.P.; Oliveira, J.A. Padrão anual de variação da testosterona sérica, volume testicular e aspectos seminais de veados-catingueiros (Mazama gouazoubira) em cativeiro. Rev. Bras. Reprod. Anim. 2001, 25, 210-211.

53. Benirschke, K. Sterility and Fertility of Interspecific Mammalian Hybrids. In Comparative Aspects of Reproductive Failure; Springer: Berlin/Heidelberg, Germany, 1967; pp. 218-234. ISBN 978-3-642-48949-5.

54. Ashley, T. An integration of old and new perspectives of mammalian meiotic sterility. Results Probl. Cell Differ. 2000, 28, 131-173. [CrossRef] [PubMed]

55. Wishart, W.D.; Hrudka, F.; Schmutz, S.M.; Flood, P.F. Observations on spermatogenesis, sperm phenotype, and fertility in white-tailed $\times$ mule deer hybrids and a yak $\times$ cow hybrid. Can. J. Zool. 1988, 66, 1664-1671. [CrossRef]

56. McEntee, K. Reproductive Pathology of Domestic Mammals; Academic Press: San Diego, CA, USA, $1990 ;$ ISBN 9780124833753.

57. Britton-Davidian, J.; Fel-Clair, F.; Lopez, J.; Alibert, P.; Boursot, P. Postzygotic isolation between the two European subspecies of the house mouse: Estimates from fertility patterns in wild and laboratory-bred hybrids. Biol. J. Linn. Soc. 2005, 84, 379-393. [CrossRef]

58. McGovern, P.T. The barriers to interspecific hybridization in domestic and laboratory mammals. II. Hybrid sterility. Br. Vet. J. 1976, 132, 68-75. [CrossRef] 
59. Jadwiszczak, K.A.; Banaszek, A. Fertility in the male common shrews, Sorex araneus, from the extremely narrow hybrid zone between chromosome races. Mamm. Biol. 2006, 71, 257-267. [CrossRef]

60. Trujillo, J.M.; Ohno, S.; Jardine, J.H.; Atkins, N.B. Spermatogenesis in a male hinny: Histological and cytological studies. J. Hered. 1969, 60, 79-84. [CrossRef]

61. Chandley, A.C.; Jones, R.C.; Dott, H.M.; Allen, W.R.; Short, R.V. Meiosis in interspecific equine hybrids. I. The male mule (Equus asinus X E. caballus) and hinny (E. caballus X E. asinus). Cytogenet. Cell Genet. 1974, 13, 330-341. [CrossRef]

62. Gray, A.P. Mammalian Hybrids. A Check-List with Bibliography; Commonwealth Agricultural Bureaux International: Buckinghamshire, UK, 1954.

63. Carranza, J.; Roldán, M.; de Fátima Carvalho Peroni, E.; Duarte, J.M.B. Weak premating isolation between two parapatric brocket deer species. Mamm. Biol. 2017, 87, 17-26. [CrossRef]

64. Bonnet-Garnier, A.; Pinton, A.; Berland, H.M.; Khireddine, B.; Eggen, A.; Yerle, M.; Darré, R.; Ducos, A. Sperm nuclei analysis of 1/29 Robertsonian translocation carrier bulls using fluorescence in situ hybridization. Cytogenet. Genome Res. 2006, 112, $241-247$. [CrossRef]

65. Barasc, H.; Mouney-Bonnet, N.; Peigney, C.; Calgaro, A.; Revel, C.; Mary, N.; Ducos, A.; Pinton, A. Analysis of Meiotic Segregation Pattern and Interchromosomal Effects in a Bull Heterozygous for a 3/16 Robertsonian Translocation. Cytogenet. Genome Res. 2018, 156, 197-203. [CrossRef] [PubMed]

66. Pinton, A.; Calgaro, A.; Bonnet, N.; Ferchaud, S.; Billoux, S.; Dudez, A.M.; Mary, N.; Massip, K.; Bonnet-Garnier, A.; Yerle, M.; et al. Influence of sex on the meiotic segregation of a $\mathrm{t}(13 ; 17)$ Robertsonian translocation: A case study in the pig. Hum. Reprod. 2009, 24, 2034-2043. [CrossRef] [PubMed]

67. Manieu, C.; González, M.; López-Fenner, J.; Page, J.; Ayarza, E.; Fernández-Donoso, R.; Berríos, S. Aneuploidy in spermatids of Robertsonian $(\mathrm{Rb})$ chromosome heterozygous mice. Chromosome Res. 2014, 22, 545-557. [CrossRef] [PubMed]

68. Wiland, E.; Olszewska, M.; Woźniak, T.; Kurpisz, M. How much, if anything, do we know about sperm chromosomes of Robertsonian translocation carriers? Cell. Mol. Life Sci. 2020. [CrossRef] [PubMed]

69. Switoński, M.; Gustavsson, I.; Plöen, L. The nature of the 1;29 translocation in cattle as revealed by synaptonemal complex analysis using electron microscopy. Cytogenet. Cell Genet. 1987, 44, 103-111. [CrossRef] [PubMed]

70. Kingswood, S.C.; Kumamoto, A.T.; Sudman, P.D.; Fletcher, K.C.; Greenbaum, I.F. Meiosis in chromosomally heteromorphic goitered gazelle, Gazella subgutturosa (Artiodactyla, Bovidae). Chromosome Res. 1994, 2, 37-46. [CrossRef] [PubMed]

71. Moritz, C. The Population Biology of Gehyra (Gekkonidae): Chromosome Change and Speciation. Syst. Biol. 1986, 35, 46-67. [CrossRef]

72. Long, S.E. Tandem 1;30 translocation: A new structural abnormality in the horse (Equus caballus). Cytogenet. Genome Res. 1996, 72, 162-163. [CrossRef]

73. Pillay, N.; Willan, K.; Meester, J. Post-zygotic reproductive isolation in two populations of the African vlei rat Otomys irroratus. Acta Theriol. 1995, 40, 69-76. [CrossRef]

74. White, M.; Blackith, R.; Blackith, R.; Cheney, J. Cytogenetics of the viatica group morabine grasshoppers. I. The coastal species. Aust. J. Zool. 1967, 15, 263. [CrossRef]

75. Cursino, M.S.; Salviano, M.B.; Abril, V.V.; dos Santos Zanetti, E.; Duarte, J.M.B. The role of chromosome variation in the speciation of the red brocket deer complex: The study of reproductive isolation in females. BMC Evol. Biol. 2014, 14, 40. [CrossRef] [PubMed] 